\section{IN THE NEWS}

Metaphorically speaking Here's a choice picking of some of the metaphors that were used to describe the human genome and its sequencing.

Donald Kennedy, editorin-chief of Science, on the efforts of the public consortium, The New York Times (US):

"Imagine trying to do this job in a number of places with academic scientists - it's like herding cats."

Francis Collins in The Washington Post (US) on the human genome: "We've called the human genome the book of life, but it's really three books. It's a history book. It's a shop manual and parts list. And it's a textbook of medicine more profoundly detailed than ever."

Eric Lander on Celera's sequence in Los Angeles Times (US):

Instead of a complete

map of DNA, Lander said, Venter wound up with "a tossed genome salad".

Francis Collins pursued the culinary metaphor in The Washington Post on the complexity of the human genome:

"We have the Cuisinart that can slice and dice and do lots of things, while worms and flies have paring knives."

John Sulston on how evolution recombines old parts, The Daily

Telegraph (UK):

"You convert your Austin

7 into a Mercedes, but basically it is the same underneath."

Craig Venter on the wonder of the genome, The New York Times:

"We feel like midgets

describing the universe and we can't comprehend it all."

\title{
Themes and variations
}

The publication of the human genome draft sequences by the International Human Genome Sequencing Consortium in Nature (15 February) and by Celera Genomics in Science (16 February), along with the accompanying research, commentary and analysis occupies almost 250 printed pages. The papers take readers on a journey through genome function and evolution, as well as through many aspects of basic and applied biology. If you haven't yet tackled them all, here is a brief digest of some of their main themes.

How does it look? This is the first view of the whole human (or any vertebrate) genome sequence. Parts of the human genome are already well charted, but now we have a vantage point which affords us a panoramic view. Although there are plenty of holes, the picture is largely consistent with previous studies: the genome is rich in repeats (about 50\%); segmental duplications are common; and $\mathrm{G}+\mathrm{C}$-rich regions tend to have more genes. But the number of genes has attracted much attention, as expressed by Gerry Rubin:

"Here is the real surprise: the human genome probably contains between 25,000 and 40,000 genes, only about twice the number needed to make a fruitfly, worm or plant."

The broad range of the estimates reflects the limitations of current gene-prediction methods, but the

\section{IN THE NEWS}

\section{Rivalry and wonder}

Given the media fanfare that accompanied the announcement of the completion of the draft human genome last June, the response of the world's press to the publication of the sequence analysis promised to be fascinating. How would this coverage shape the public's perception of this landmark achievement?

What comes across foremost in the media is that this scientific milestone brims with human emotion. The acrimony and rivalry between the public and private efforts is heaven-sent news fodder, and so was the focus of many reports that came out a day early because of an embargo-breaking article in UK's The Observer newspaper on 11 February.

As reported by US's The Washington Post on 12 February: Celera's plans set off a ferocious struggle over egos, research technique and scientific principle. As of this week, the results are finally available in a scientific journal and the big question is:
Did the grand experiment work? "It worked beautifully", Venter said. "It didn't work", said Eric Lander.

Why the members of the public consortium felt this way was explained in UK's The Daily Telegraph:

Their conclusion: Celera had underplayed its dependence on public data; it had a less complete genome than the public effort; its much-vaunted faster method for reading DNA had run into difficulties..

"The whole genome assembly method has not worked as hoped. It has not given them enough continuity to reasonably map [their sequence] on the human genome without leaving a lot of gaps", said Sir John [Sulston]. "All the king's horses and all the king's men could not put the genome together again", said Eric Lander, in US's Los Angeles Times.

Mark Adam's (of Celera) explanation came in US's

The New York Times:

"We did not attempt to order the whole-genome scaffolds on the chromosomes because it's a lot of work and we had made the commitment to this [approach] and that's the one we were going to go forward and publish." Adams said the company could have assembled the scaffolds to cover more than $90 \%$ of the DNA puzzle had it chosen to.

And in the The Washington Post: Venter said it was unfortunate that his rivals had "got their panties in a gather" once again over the issue of whose gene-analysis technique is better.

Few newspapers took sides in this argument, but the German paper Frankfurter Allgemeine took a cautionary stance: Academia is pursuing its role as Mr. Venter's teacher with such fervor that it is in danger of losing sight of reality... It is no more possible to conceive of the future of molecular biology... without involving research industry than it is without basic research. 